\title{
Dead wood quality influences species diversity of rare cryptogams in temperate broadleaved forests
}

\author{
Zydrunas Preikša ${ }^{(1)}$, Gediminas \\ Brazaitis ${ }^{(2)}$, Vitas Marozas ${ }^{(1)}$, \\ Bogdan Jaroszewicz ${ }^{(3)}$
}

\begin{abstract}
Dead wood is one of the most important indicators of forest naturalness and the most important manageable habitat for biodiversity in forests. Standing and lying dead wood, and especially coarse woody debris, plays an important part in creating habitats for many highly specialized organisms, e.g., insects, fungi, lichens and bacteria. Temperate mixed deciduous forests, rich in species, have been studied only to a small extent from the point of view of the ecology of wood-related cryptogams. Our study aimed at the reduction of the gap in knowledge about the ecological characteristics of dead wood-dependent organisms by focusing on species of cryptogams developing on various dead wood structures typical of temperate non-beech forests. Studies were performed in forests located in Lithuania, Poland, Belarus and Russia. We recorded 48 species of cryptogams: 18 species of bryophytes, 24 species of fungi and 6 species of lichens developing on dead wood. Our study stresses the importance of all types of dead wood as a substrate for the development of rare cryptogam species. Logs were the most important substratum type for cryptogams, followed by snags, dead trees and stumps. The cryptogam species richness on logs was several times higher than on the three other types of substrata. Coarse logs of intermediate decay stages hosted the highest number of cryptogams, followed by freshly fallen logs and, finally, well decayed logs. Assessing the importance of dead wood quality for the studied cryptogams, we found that intermediate decay stages are extremely important for fungi, while bryophytes or lichens do not show a clear preference. The highest number of cryptogams was found on Fraxinus excelsior, Quercus robur and Picea abies, while other tree species had less than half cryptogam species.
\end{abstract}

Keywords: Macrolichens, Fungi, Bryophytes, Tree Species, Indicator Species, Decay Stages
Associations between dead wood quality and quantity, and dead wood-dependent organisms have most intensively been studied in the boreal forests of Europe and North America (McAlister 1997, Kuusinen \& Siitonen 1998, Kruys et al. 1999, Qian et al. 1999, Jacobs et al. 2007, Djupstrom et al. 2008, Fenton \& Bergeron 2008). In Scandinavia and the Baltic states saproxylic species are used as indicators for the evaluation of woodland key habitats (Gustafsson et al. 1999), understood as areas where
(1) Institute of Environment and Ecology, Aleksandras Stulginskis University, Studentu 11, LT-53361, Kaunas region, Akademija (Lithuania); (2) Institute of Forest Biology and Silviculture, Aleksandras Stulginskis University, Studentu 11, LT-53361, Kaunas region, Akademija (Lithuania); (3) Bialowieza Geobotanical Station, Faculty of Biology, University of Warsaw, Sportowa 19, PL 17-230, Bialowieza (Poland)

@ Zydrunas Preikša (griciukas@gmail.com)

Received: Oct 22, 2014 - Accepted: May 18, 2015

Citation: Preikša Z, Brazaitis G, Marozas V, Jaroszewicz B (2015). Dead wood quality influences species diversity of rare cryptogams in temperate broadleaved forests. iForest 9: 276-285. - doi: 10.3832/ifor1483-008 [online 2015-09-28]

Communicated by: Massimo Faccoli one or more red-listed species occur, or where the likelihood of finding red-listed species is high owing to the nature of the forest (Nitare \& Norén 1992). Less intensive studies on this subject have been carried out in the beech forests of western and central Europe and southern Sweden (Norden et at. 2004, Heilmann-Clausen \& Christensen 2004, Odor \& van Hees 2004, Christensen et al. 2005, Heilmann-Clausen \& Christensen 2005, Juutilainen et al. 2011). Although temperate mixed deciduous forests occupy vast areas of eastern Europe (from Poland to Ural mountains), such studies are scarce and limited to a few sites in Poland (e.g., the Bialowieza Forest - Falinski \& Mulenko 1995, Chlebicki et al. 1996) and Lithuania (Iršenaite \& Kutorga 2006). Addressing this large gap in knowledge on the ecology of wood-related cryptogams is fundamental, since mixed deciduous oakdominated forests have the highest biological diversity among all temperate forests in Europe (Nilsson et al. 2001). Moreover, this forest type is among the most endangered biomes worldwide due to human impact (Hannah et al. 1995, Peterken 1996). Even the Bialowieza Forest, that is considered the best preserved temperate lowland forest in Europe, has been affected to 


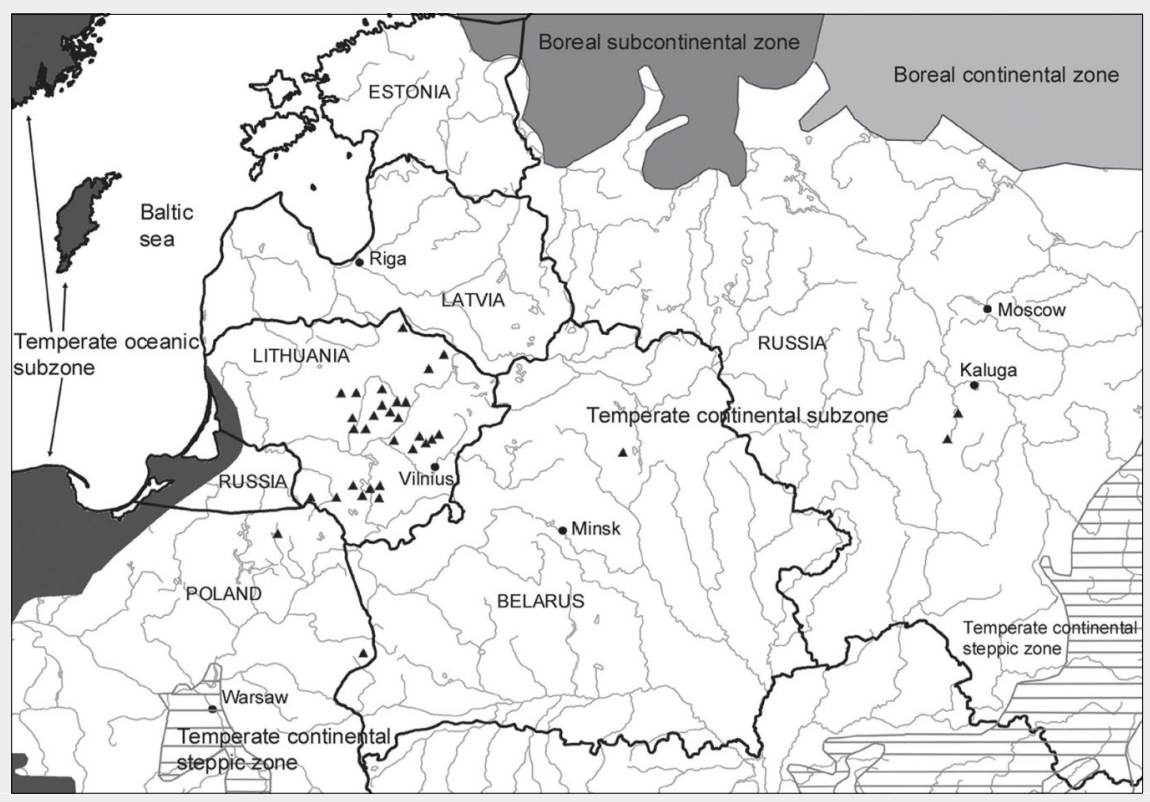

Fig. 1 - Location of study sites (black triangles). Boundaries of bioclimatic zones follow Rivas-Martinez et al. (2004).

some extent by past management (Bobiec 2012). Anthropogenic pressures on temperate mixed forests in Europe is expected to increase in the future due the large population in this area. Furthermore, current policy in Europe is oriented at using more renewable energy resources, including firewood. Indeed, in many European countries fine branches or small pieces of wood are removed from the forest stands for the production of bioenergy (Lundborg 1998, Malinen et al. 2001), and even stumps, which constituted up to $75 \%$ of all dead wood in intensively managed forests, are often extracted (Burrascano et al. 2008, Walmsley \& Godbold 2010). Such changes in the use of forest products does not favor the accumulation of dead wood stocks in forests. On the other hand, dead wood is considered one of the most important indicators of forest naturalness, and the most important manageable habitat for biodiversity in forests (Huston 1996).

Saproxylic organisms (including cryptogams) have been reported to largely contribute to forest biodiversity (Niemelä et al. 1995). They are among the most threatened organisms in Europe, and are considered a major conservation issue since their habitat is one of the most consumed forest products - dead wood (Berg et al. 1994, Samuelsson et al. 1994). Therefore, knowledge about the ecological preferences of these species is needed to undertake effective measures for their conservation in both managed and protected forests.

This study focused on the ecological characteristics of the cryptogam species colonizing various dead wood structures in temperate non-beech broadleaved oldgrowth forests. The importance of the different kinds of dead wood (including stumps) for such groups of organisms was assessed by exploring: (1) the overall prefe- rence of rare cryptogam species in terms of type, size and decay stage of dead wood; (2) the cryptogam preferences in terms of tree species of the dead wood; (3) the cryptogam colonization rates of dead wood, including quantitative and qualitative aspects.

\section{Material and methods}

\section{Study area}

The study was carried out over a vast area in eastern and central Europe enclosed between $52^{\circ} 43^{\prime}$ and $56^{\circ} 23^{\prime} \mathrm{N}$ of latitudes and between $22^{\circ} 04^{\prime}$ and $35^{\circ} 52^{\prime} \mathrm{E}$ of longitude (Fig. 1). One-hundred sample plots covering a total area of 19.6 ha (see below) were selected in 34 different forest stands in Lithuania (78 sample plots), two in Poland (10 plots), one in Belarus (4 plots), and two in Russia (8 plots). The selected stands varied from semi-open to very dense, and their mean age was 110 years (range: 70-180 years). According to the bioclimatic map of Europe (Rivas-Martinez et al. 2004), the whole study area lies in the temperate zone, temperate-continental variant. The forests in this area belong to Europe's mixed forest zone, which is a transitional variant between northern coniferous forests and western European deciduous forests.

Twelve different tree species were detected over all the studied stands ( 1 to 9 tree species per plot, 5.7 species on average). The most abundant species was Quercus robur L. (26\% of the stands' composition on average); other species were Picea abies (L.) H. Karst. (16\%), Tilia cordata L. (15\%), Fraxinus excelsior L. (13\%), Acer platanoides L. (7\%), Populus tremula L. (7\%); the least abundant species found were Carpinus betulus L. (5\%), Betula pendula L. (5\%), Alnus glutinosa L. (4\%), Ulmus glabra L.
(1\%), Alnus incana L. (1\%) and Pinus sylvestris L. $(<1 \%)$.

Understory in the studied plots was dominated by Corylus avellana L., with density varying from very sparse to very dense. A high admixture of Acer campestre was observed in Russian sites. Other species (Lonicera xylosteum, Frangula alnus, Sorbus aucuparia) were scarce. Nearly half of the plots $(48 \%)$ were located on fresh soils, while the other half $(49 \%)$ on temporary wet soils. Only a few studied plots (3\%) were located on constantly wet soils. Most plots $(58 \%)$ were established on very fertile soils, about one-third (31\%) on extremely fertile soils, and some others (11\%) on fertile soils. About one third of the plots (34\%) were located in strict reserves or natural parks (highest conservation priority sites), $31 \%$ in managed reserves or forests of ecological protection zones, and 35\% in commercial forests.

\section{Site and plot selection}

Study sites were selected using the stratified sampling method (Bunce et al. 1983). For site selection forest stands' age, dominant tree species, forest management intensity and relief were considered. According to such criteria, all forests larger than 500 ha were selected in Lithuania. In Poland, Belarus and Russia the best preserved eastern and central European lowland forests outside the beech (Fagus sylvatica L.) distribution range were selected, where no forest management had taken place for at least 50 years.

The study plots ( $25 \mathrm{~m}$ radius circle, 0.196 ha, at least $100 \mathrm{~m}$ apart from clearcuts or forest edges) were established in the most representative part of typical deciduous or mixed deciduous stands, with broadleaves' share exceeding $20 \%$ of the stand composition. Only stands larger than 2 ha were chosen, in order to avoid the influence of adjacent stands, different in age, species composition, or characterized by major disturbances. Stands on slopes were also avoided.

Sampled trees were at the age limit of commercial forest logging maturity in Lithuania (Quercus robur: 120 years; Fraxinus excelsior: 100; Acer platanoides: 100; Ulmus spp.: 100; Tilia cordata: 60; Carpinus betulus: 60). Among conifers, only Norway spruce (Picea abies) dominated on the plots.

\section{Data collection}

Sampling was carried out from August to October. All plots were carefully investigated within 2-6 hours, depending on the complexity of the plot structure and the number of species found.

The coarse woody debris (CWD) considered in this study included dead trees, snags, logs and stumps. Dead trees comprised standing dead trees still with branches and trunk diameter at breast height $(\mathrm{DBH}) \geq 30 \mathrm{~cm}$. Snags included standing parts of trunk with no or very few bran- 
ches, with height $>1 \mathrm{~m}$ and $\mathrm{DBH} \geq 15 \mathrm{~cm}$. Logs were uprooted, or hanging parts of trunk up to 45 degrees, or fallen large branches with diameter $>15 \mathrm{~cm}$ and over 1 $\mathrm{m}$ long. Stumps of natural (broken) and artificial (cut) origin were considered as separate types of CWD. Stumps were taken into account only if larger than $20 \mathrm{~cm}$ in diameter at their top. Fine dead wood (FWD) was taken into consideration only in cases when it was inhabited by an indicator species. FWD are all smaller substrate units of all the dead wood types described above (dead tree, snag, log and stump).

All logs with the thicker end within plot limits were included in the plot. If the thicker end was outside the plot, despite most of the log being inside, it was excluded. Thinner parts of the log were not included in biomass analyses. CWD volume was calculated for logs only for parts thicker than $15 \mathrm{~cm}$ in diameter using the cylinder formula (eqn. 1):

$$
V=\frac{L \pi D^{2}}{4}
$$

where $V$ is wood volume $\left(\mathrm{m}^{3}\right), L$ is the length of the $\log (\mathrm{m}), D$ is the mean log diameter $(\mathrm{m})$ calculated as the sum of log diameter at the thicker and at the thinner end divided by two.

For each log and stump, decay stage was determined using a 5 point scale (Waddell 2002):

1. fresh log, without signs of decay, small branches and bark still attached to the log;

2. more or less solid log, starting to decay, sapwood partially soft, small branches usually detached, bark partially gone;

3. moderately decayed, barkless log, large pieces of wood easily removable by hand;

4. sapwood strongly decayed, log still holding shape;

5. $\log$ soft and powdery, does not hold shape. For this stage volume was not calculated.

Decay stage was not evaluated for standing dead trees and snags because in most cases they were only at the initial stages.

Generalist species inhabiting dead wood were not taken into consideration. Abundant and widely regionally dispersed (generalist) species do not require special habitat conditions, have good dispersal abilities, and can be found in various successional stages and types of forests of various management regimes (Hanski et al. 1993, Kuusinen 1996b). Because studying all species of all systematic groups of organisms at one time, especially when working on larger territories, would be too difficult, inconvenient or expensive, we used a smaller number of indicator species as indicators of biodiversity for ecologically sustainable forest management. This approach is a good alternative and is quite often applied in practice (Peterken 1996, Lindenmayer et al. 2000, Nilsson et al. 2001, Motiejunaite et al. 2004). Specialized (indicator) species show the presence of very specific habitat conditions and high probability to find other, less sensitive species (Rose 1992, Kuusinen 1995, Kuusinen 1996a, Ulicka \& Angelstam 2000). Therefore, we took into account only oldgrowth forest indicator species of cryptogams: bryophytes (green mosses Bryopsida and liverworts Hepaticopsida), macrolichens (foliose and fruticose species), and wood-inhabiting fungi (Basidiomycetes). This was a slightly modified Woodland Key Habitat (WKH) indicator species list, created for the WKH inventory in Lithuania (Andersson et al. 2002). The nomenclature of green mosses was adopted after Jukoniene (2003), liverworts after Naujalis et al. (1995), wood-inhabiting fungi after Gricius \& Matelis (1996) and macrolichens after Motiejunaite (2002).

The colonization efficiency of cryptogam species was evaluated for CWD of each decay class and each tree species. Colonization efficiency was calculated as the ratio between the number of logs colonized by cryptogams and the total number of logs.

\section{Data analysis}

Three quantitative species evaluation indexes per plot were calculated: species richness (mean number of indicator cryptogam species), relative species richness (mean number of indicator cryptogam species per substratum unit), and abundance of cryptogams (total number of specimens of all studied species found on all substrata units in the plot). For the evaluation of species richness of the whole sample (i.e., plot), we used the term "total species richness", and for the abundance of the whole sample - "total abundance". We used the expression "substratum unit" throughout the paper for any single stump, log, dead standing tree or snag. The species richness for cryptogams recorded on the studied substrata was compared by sample-based rarefaction. To estimate the true species richness of cryptogams colonizing deadwood we used Chaor estimators of total species richness, that usually perform better than other estimators (Colwell \& Coddington 1994).

All tests were performed using the STATISTICA ${ }^{\circledast}$ software package (StatSoft, Tulsa, OK, USA) and ad-hoc formulas in Microsoft Excel ${ }^{\oplus}$, with the exception of the calculation of Chaor estimators and the rarefaction analysis, that was carried out

Tab. 1 - Total species richness and estimated species richness of cryptogams recorded on dead standing trees, snags, logs and stumps in eastern and central European mixed deciduous forests.

\begin{tabular}{|c|c|c|c|c|c|}
\hline \multirow[b]{2}{*}{ Substrate } & \multirow[b]{2}{*}{$\begin{array}{l}\text { Number } \\
\text { of units }\end{array}$} & \multirow{2}{*}{$\begin{array}{l}\text { Number of } \\
\text { recorded } \\
\text { species }\end{array}$} & \multicolumn{3}{|c|}{ Chao2 } \\
\hline & & & Mean & $\begin{array}{l}\text { Lower } \\
95 \% \mathrm{Cl}\end{array}$ & $\begin{array}{l}\text { Upper } \\
95 \% \mathrm{Cl}\end{array}$ \\
\hline Dead trees & 230 & 12 & 19.96 & 12.98 & 76.54 \\
\hline Snags & 272 & 15 & 15.39 & 15.02 & 20.29 \\
\hline Logs & 1674 & 43 & 63.31 & 47.66 & 130.10 \\
\hline Stumps & 946 & 16 & 47.96 & 20.83 & 227.35 \\
\hline
\end{tabular}

by the software Estimates 9.1.0 (Colwell 2013). Hypothesis testing was performed through the use of general linear models (GLMs - Jaeger 2008). We used nested ANOVA design for comparison of species richness and relative species richness of cryptogams within each taxa among substrate types and substrate decay stages. Cryptogam type, decay stage and substrate type were categorical predictors for dependent variables (species richness or relative species richness). On nested ANOVA the decay stage or substate type were nested into the cryptogam type. The data was nested by study design (not naturally nested) to show the main effect of the decay stage or substrate type within the analyzed cryptogam taxa group (Schielzeth \& Nakagava 2013). We discarded the two-way factorial scenario as it includes the interaction effect between factors (bryophytes, fungi and macrolichens in our case), which are obviously different in our study. The differences between natural nesting and nesting by design will become important when it comes to interpretation of the variance explained by the nested factor. Nested effects are effects in which the nested variables never appear as main effects. The interpretation of results should reflect the fact that the interaction variance inflates the main effect variance when dealing with nested data structures (Schielzeth \& Nakagava 2013). The sigma-restricted coding method is overly-restrictive for nested designs, so only the over-parametrized model is used to represent nested designs.

Differences in cryptogam colonization efficiency on CWD among the decay class proportions of different tree species were tested using the chi-square test. The chisquare test was applied only if at least $80 \%$ of the cells had an expected frequency of 5.0 or greater, and no cells had an expected frequency smaller than 1.0. If these requirements were not met, the Fisher's exact probability test was used.

\section{Results}

\section{Dead wood characteristics}

Overall, 3122 substrata units were examined in this study (Tab. 1). The mean number of standing dead trees per plot was 2.3 \pm 0.24 (SD), varying from 0 to 11 dead trees, and with $28 \%$ of plots without any dead tree ( $\operatorname{mode}=0$, mode frequency $=28$ ). Six species of dead trees were recorded in 
Tab. 2 - Mean amount of stumps and downed coarse woody debris ( \pm standard deviation) per study plot (0.196 ha).

\begin{tabular}{lcccccc}
\hline \multirow{2}{*}{$\begin{array}{l}\text { Dead wood } \\
\text { type }\end{array}$} & \multicolumn{4}{c}{ Dead wood decomposition stage } & \multirow{2}{*}{$\begin{array}{c}\text { Total } \\
\text { mean }\end{array}$} \\
\cline { 2 - 6 } & $\mathbf{1}$ & $\mathbf{2}$ & $\mathbf{3}$ & $\mathbf{4}$ & $\mathbf{5}$ & $7.04 \pm 0.64$ \\
\hline Logs (m ${ }^{3}$ ) & $2.13 \pm 0.25$ & $2.62 \pm 0.31$ & $2.07 \pm 0.35$ & $0.21 \pm 0.05$ & - & $16.70 \pm 1.17$ \\
Logs (units) & $4.80 \pm 0.48$ & $6.30 \pm 0.53$ & $4.70 \pm 0.49$ & $1.00 \pm 0.16$ & - & \\
Stumps & $0.80 \pm 0.15$ & $2.20 \pm 0.32$ & $3.70 \pm 0.40$ & $3.50 \pm 0.43$ & $0.50 \pm 0.10$ & $10.80 \pm 0.86$ \\
(units) & & & & & & \\
\hline
\end{tabular}

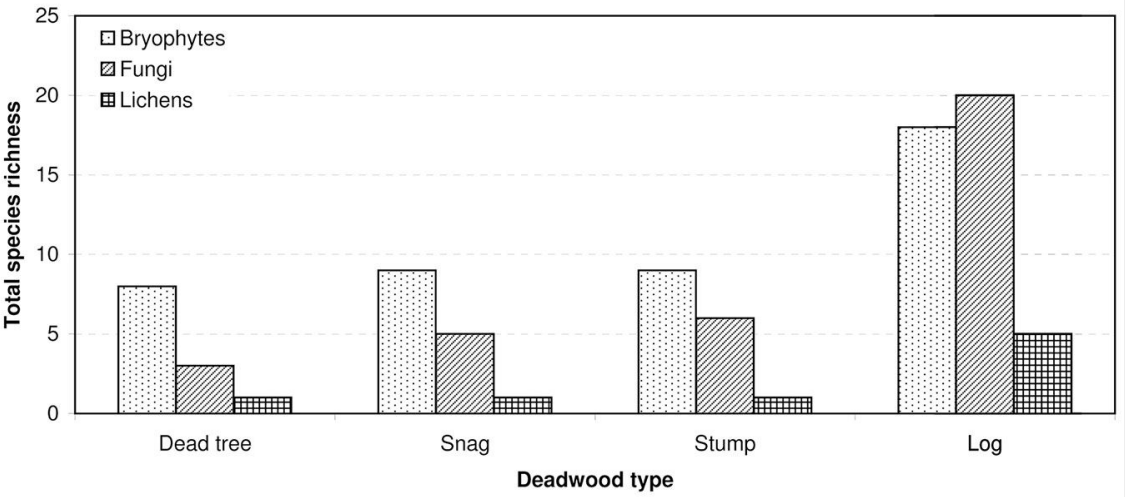

Fig. 2 - Total species richness recorded on different types of coarse woody debris.

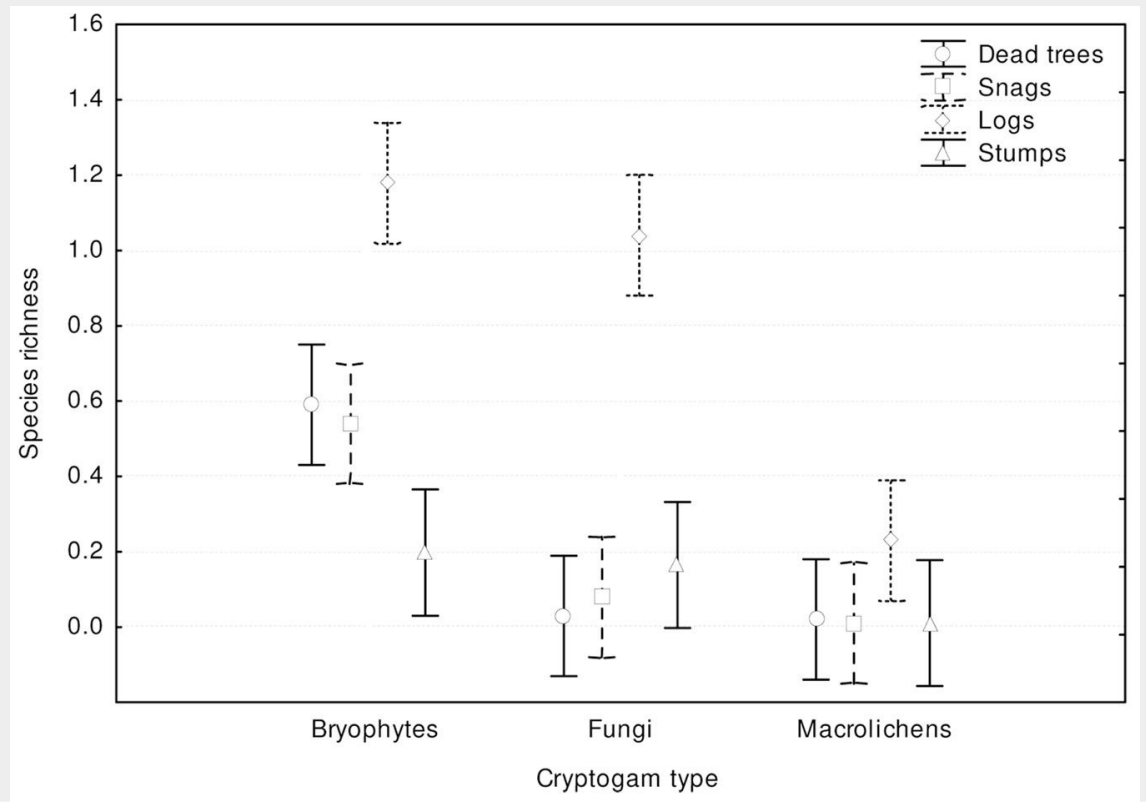

Fig. 3 - Differences in cryptogam species richness among substrate types $\left(F_{[9,161]}=\right.$ 20.061; $\mathrm{p}<0.0001$ ). Bars represent the standard deviation from the mean.

total: the most common were Quercus robur (1.4 tree/plot), Picea abies and Fraxinus excelsior (both 0.4 tree/plot). The mean number of snags per plot was similar to the number of dead trees: $2.7 \pm 0.24$ (ranging from 0 to 13 ), although $28 \%$ of the stands had only 1 snag (mode $=1$, mode frequency=28). Snags of 11 tree species were registered in total, the most common being Picea abies (0.9 snag/plot) and Betula pendula ( 0.4 snag/plot). The first decay stage dominated among standing dead trees, and only a very few standing trees reached the successive decomposition sta- ges. Snags had decomposition of wood further advanced than dead trees, but the first decay stage still dominated.

The mean volume of downed CWD was $7.04 \pm 0.64 \mathrm{~m}^{3}$ per plot $\left(35.92 \mathrm{~m}^{3}\right.$ ha-1), varying from 0 to $27.16 \mathrm{~m}^{3} /$ plot (from 0 to $138.57 \mathrm{~m}^{3} \mathrm{ha}^{-1}$ ). Most of the fallen logs were at the second stage of decomposition (Tab. 2). The mean number of stumps per plot was $10.8 \pm 0.86$ (range: 1-34). On average, this included 3.0 natural stumps (ranging from 0 to 12) and 7.5 artificial (cut) stumps (varying from o to 34). Most stumps were at the third or fourth decay stages (Tab. 2).

\section{Cryptogam species richness and} abundance

Overall, 48 species of indicator cryptogam species on dead wood were recorded: 18 species of bryophytes, 24 species of fungi, and 6 species of macrolichens (see Appendix 1). In total, 1008 records of indicator species of cryptogams were taken on 775 substrata units: 641 records of bryophytes (on 498 substrata units), 308 records of fungi (on 278 substrata units), and 59 records of macrolichens (on 55 substrata units).

In $79.5 \%$ of the cases only one species of indicator cryptogam was recorded on a single substratum unit, two species per unit of dead wood were recorded in $13.4 \%$ of cases, three species in $5.3 \%$ of cases, four species in $1.5 \%$ of cases, five and six species in $0.1 \%$ of cases each.

The most common species was the bryophyte Ulota crispa, recorded on 125 different substrata units. Among fungi the most common was Xylobolus frustulatus, recorded on 105 separate substrata units, and among macrolichens Cetrelia olivetorum, recorded on 20 separate substrata units. Eleven species were recorded only once. The abundance and the relative abundance of cryptogam taxonomic groups differed significantly. Bryophytes were the most abundant, while macrolichens were the least abundant.

\section{Cryptogam distribution according to dead wood types}

Most records of cryptogams (59\%) were taken on logs, much fewer on snags $(20 \%)$ and dead trees (16\%), and only $5 \%$ on stumps. Species richness, relative species richness, and the distribution of cryptogams among dead wood types were significantly different $(p<0.0001)$. The logs were characterized by both the highest species richness (Fig. 3) and the total species richness (Fig. 2): 43 cryptogam species out of the 48 registered on all types of substrata were registered on logs. The species richness and the total species richness of the other three types of CWD were almost equal: 12 species were recorded in total on dead standing trees, 15 species on snags, and 16 on stumps. We observed lower species richness in comparison to dead trees and snags only for bryophytes on stumps. In contrast to species richness, standing dead trees and snags were characterized by the highest relative species richness of bryophytes, and much lower on downed dead wood (logs) and stumps (Fig. 4). The relative species richness of fungi and macrolichens was very similar on all the types of substrata. GLM parameters, design and results are presented in Tab. 3 . Cumulative species richness curves (Fig. 5) showed that logs were the most important substrate for cryptogams, while stumps were the least important. Chaoz estimators of total species richness showed that only some infrequent species may not have been detected on dead standing trees and 
snags. Estimations for logs were close to $50 \%$ higher and for stumps were three times higher than the number of species recorded on these substrata. In both cases (logs and stumps) the lower limit of the 95\% confidence intervals for Chao2 estimators was higher than the number of recorded species (Tab. 1).

\section{Coarse vs. fine dead wood}

Differences in cryptogam abundance between CWD and FWD were not significant for standing dead trees when absolute numbers were considered (58 records on CWD vs. 63 on FWD). However, cryptogams on fine snags were more abundant than on coarse snags (102 vs. 54 records, respectively). Contrastingly, on coarse logs cryptogams were more abundant than on fine logs (341 vs. 116 records, respectively). The total species richness of all cryptogam taxonomic groups was higher on CWD than on FWD: 12 vs. 9 species on standing dead trees, 15 vs. 8 on snags, 43 vs. 24 species on logs, respectively. Stumps were not considered in this analysis.

Among bryophytes 17 species were recorded on CWD and 12 on FWD; among fungi 20 species on CWD and 8 on FWD; among macrolichens 5 species on CWD and 3 on FWD. In total, 20 species of cryptogams were recorded exclusively on CWD, and only one species (Trichocolea tomentella) exceptionally on FWD.

\section{Decay stages}

The observed distribution of CWD between decomposition stages was uneven. Most logs were in the second (141 units) or the third (103 units) stages of decay. Pooled together, these two decay stages hosted the greatest number of the studied cryptogams ( $71.5 \%$ of records). The lowest number of logs with rare cryptogam species was recorded in the fourth decay stage, with only 11 logs registered, and only $6.4 \%$ of cryptogam records. The species richness of cryptogams varied according to

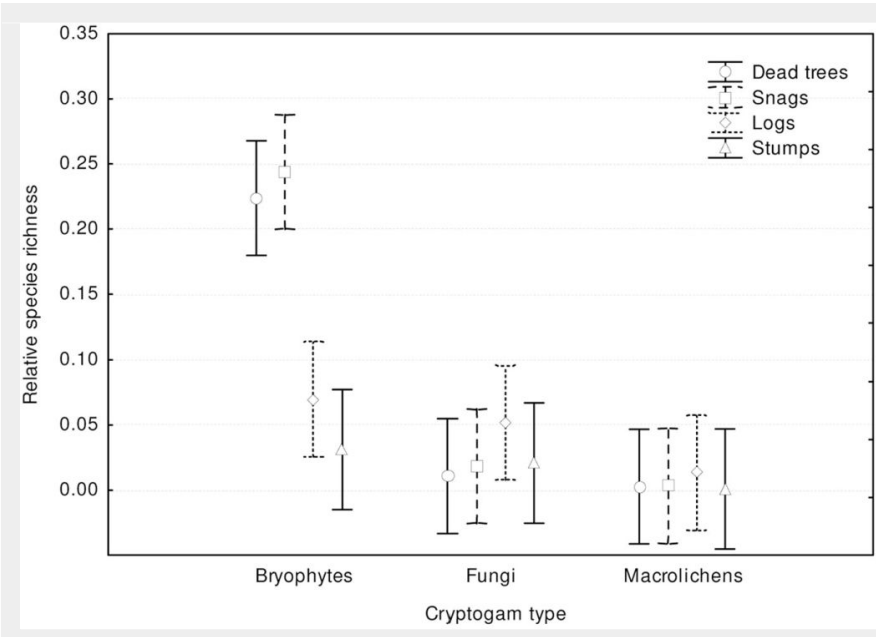

Fig. 4 - Differences in cryptogam relative species richness among substrate types $\left(\mathrm{F}_{[9,1161]}\right.$ $=7.6105 ; \mathrm{p}<$ $0.00001)$. Bars represent the standard deviation from the mean.

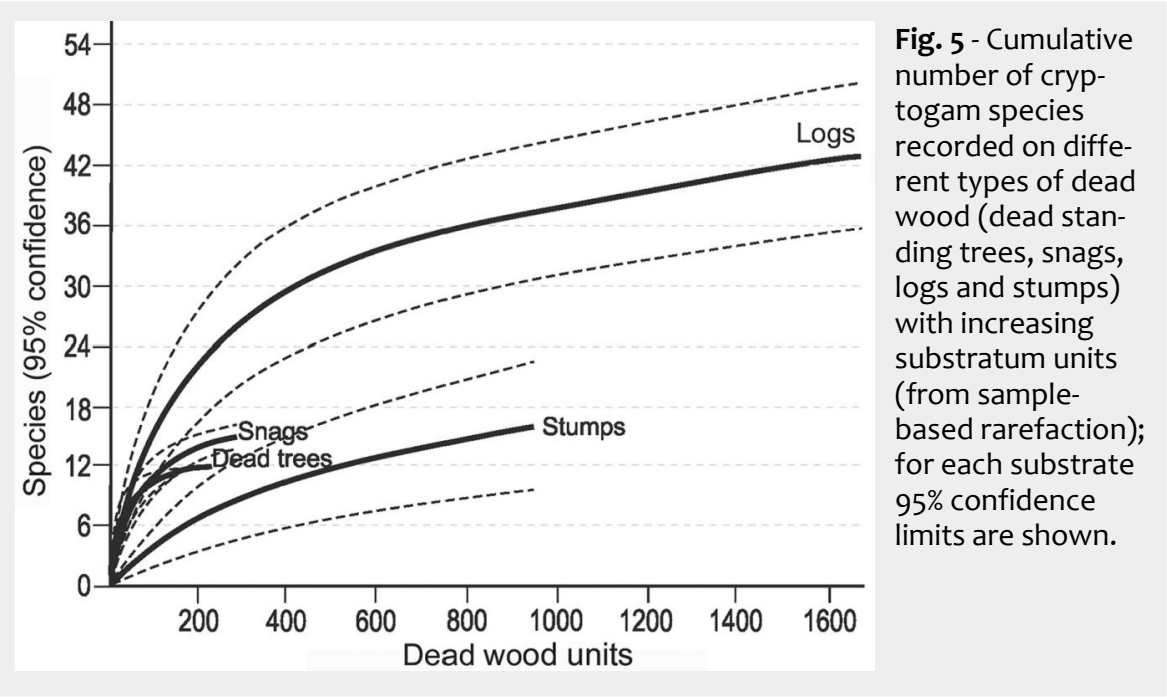

wood decay stage and taxonomic group. The total species richness of fungi reached its maximum in the middle stages of decomposition. The total species richness of bryophytes and macrolichens decreased with advancing wood decomposition (Fig. 6).

among dead wood decay stages (Fig. 7) showed significant differences $(p<0.001)$ and was similar to total species richness (Fig. 6). Bryophytes and macrolichens were most abundant on fresh dead wood, followed by decay stages 2, 3 and 4, while fungi were most abundant on wood in deCryptogam species richness distribution cay stages 2 and 3, followed by decay sta-

Tab. 3 - Results of the nested ANOVA carried out for comparison of species richness and relative species richness of cryptogams within each taxa among substrate types and substrate decay stages.

\begin{tabular}{llrrrrr}
\hline GLM Design & Effect & \multicolumn{1}{c}{ SS } & \multicolumn{1}{c}{ DF } & \multicolumn{1}{c}{ MS } & F & P \\
\hline Substrate type (Cryptogam type) & Intercept & 136.279 & 1 & 136.279 & 205.342 & 0.00001 \\
on Total species richness & Cryptogam type & 61.124 & 2 & 30.562 & 46.045 & 0.00001 \\
& Substrate type (Cryptogam type) & 119.827 & 9 & 13.314 & 20.061 & 0.0001 \\
& Error & 770.516 & 1161 & 0.664 & - & - \\
& Intercept & 3.880 & 1 & 3.880 & 77.027 & 0.00001 \\
Substrate type (Cryptogam type) & Cryptogam type & 4.268 & 2 & 2.134 & 42.361 & 0.00001 \\
on Relative species richness & Substrate type (Cryptogam type) & 3.450 & 9 & 0.383 & 7.611 & 0.00001 \\
& Error & 58.483 & 1161 & 0.050 & - & - \\
& Intercept & 71.541 & 1 & 71.541 & 176.004 & 0.00001 \\
Decay stage (Cryptogam type) & Cryptogam type & 19.982 & 2 & 9.991 & 24.579 & 0.00001 \\
on Total species richness & Substrate type (Cryptogam type) & 34.588 & 9 & 3.843 & 9.455 & 0.00001 \\
& Error & 482.89 & 1188 & 0.406 & - & - \\
& Intercept & 1.856 & 1 & 1.856 & 123.333 & 0.00001 \\
Decay stage (Cryptogam type) & Cryptogam type & 0.626 & 2 & 0.313 & 20.807 & 0.00001 \\
on Relative species richness & Substrate type (Cryptogam type) & 0.458 & 9 & 0.051 & 3.382 & 0.00042 \\
& Error & 17.876 & 1188 & 0.015 & - & - \\
\hline
\end{tabular}




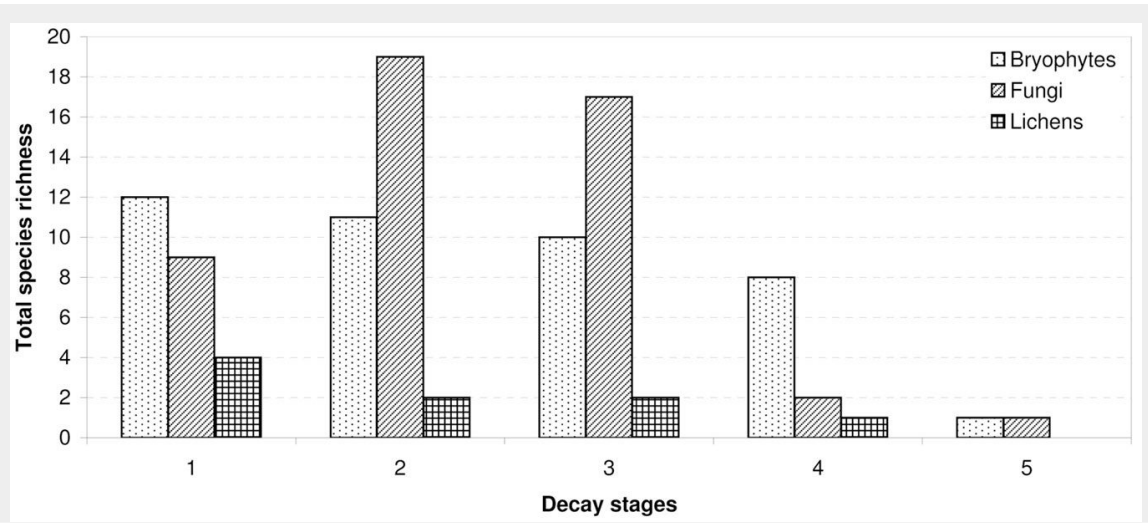

Fig. 6 - Total cryptogam species richness recorded on wood of different decay stages.
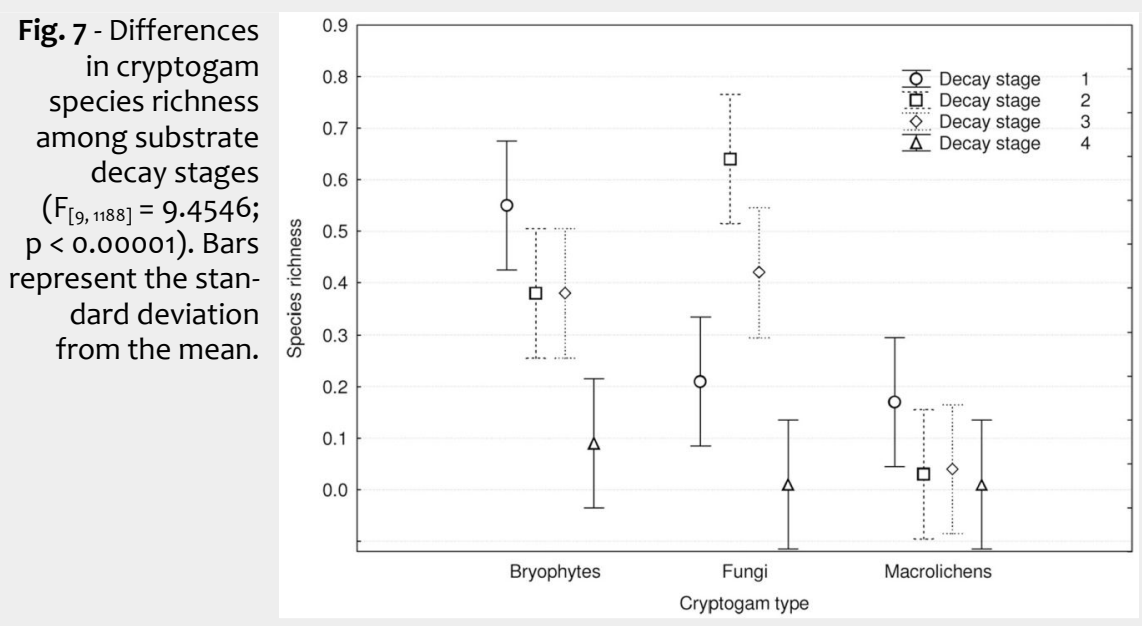

Fig. 8 - Differences in relative cryptogam species richness among substrate decay stages $\left(\mathrm{F}_{[9,1188]}=\right.$ $3.3815 ; \mathrm{p}=$

$0.00042)$.Bars represent the standard deviation from the mean.

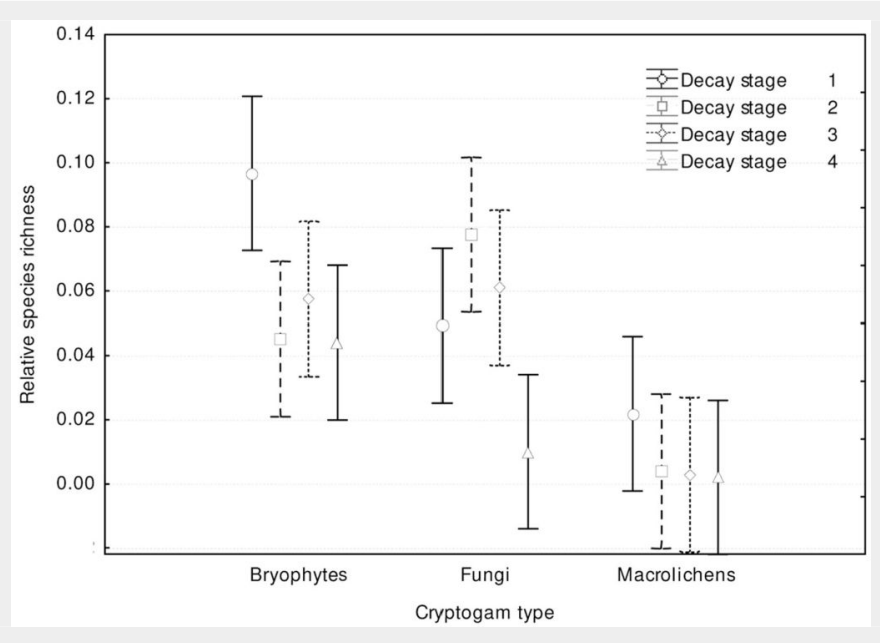

Fig. 9 - Total cryptogam abundance according to the dead wood tree species.

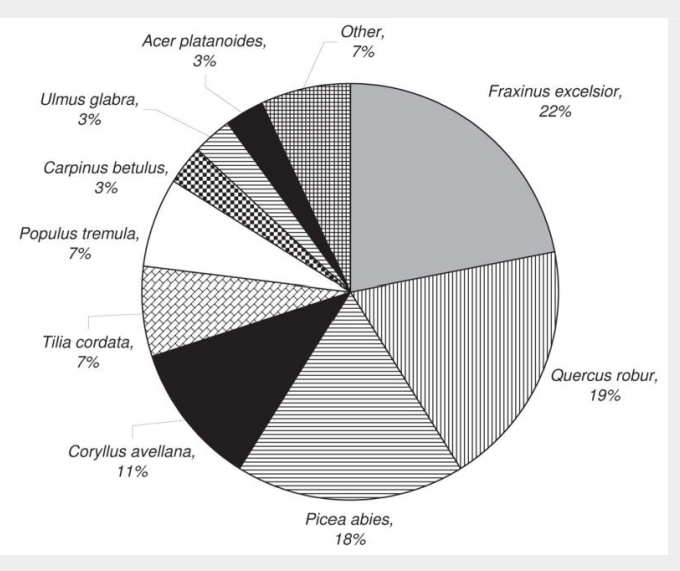

ges 1 and 4. Relative species richness (Fig. 8 ) showed similar tendencies $(p<0.001)$. GLM parameters, design and results are presented in Tab. 3.

\section{Tree species}

We recorded the highest total abundance of cryptogams on dead wood of Fraxinus excelsior, Quercus robur and Picea abies (close to $20 \%$ abundance each). The other tree species in the plots were at least half as important as substrates (Fig. 9).

Cryptogam species colonization efficiency of CWD was very different among tree species (Tab. 4). Corylus avellana was not considered in this analysis. The highest colonization efficiency was recorded for CWD of Quercus robur and the lowest for Betula pendula. The highest number of species developed on CWD of Fraxinus excelsior and Picea abies, while the lowest was on Betula pendula and Tilia cordata (Tab. 4).

\section{Discussion}

In this study, downed CWD (logs) was the most important dead wood type for the development of rare species of cryptogams, and the Chaor estimator of total species richness suggests that the importance of this substrate is potentially even higher than detected in our study. Close to 90\% of all cryptogam species developed on logs, although logs were also the most numerous substratum type in the study plots. However, such preference for logs was detected by all taxonomic groups covered by our survey. This is in line with the conclusions of Lindblad (1998), and Iršenaite \& Kutorga (2006), who found logs to be the most important substratum, especially for fungi. Studies carried out in Scandinavian boreal mesic and old-growth forests report that logs are not particularly important for lichens (Ohlsson et al. 1997), which could be due to differences in tree species composition between their coniferdominated boreal forests and the deciduous-dominated temperate forests studied here. Conifers often lose their bark when standing dead and then fall down, while in most cases deciduous trees fall with bark, which is usually already colonized by some epiphytes, thus creating very different conditions for the colonization and development of dead wood-growing species compared to debarked trunks.

Some authors emphasize the importance of snags as key habitats, especially for crustose lichens (Esseen et al. 1997, Lohmus \& Lohmus 2001), standing dead trees for all lichens (Kuusinen \& Siitonen 1998), and stumps for bryophytes and some lichens (Lindholm 2001, Humphrey et al. 2002). Our results suggest that standing dead trees and snags are colonized by cryptogams with doubled higher constancy (in terms of relative number of species) than logs and stumps, although their total species richness is three times lower than that of logs. It is worth noting that estimations of total species richness (Chaoz) on these two sub- 
strata were close to the real species richness detected in our study. Thus, an increasing number of dead trees and snags will not necessarily cause an increase in the cumulative number of species recorded. In our study snags, stumps and dead standing trees hosted nearly the same absolute number of rare cryptogam species. This is in line with the work of Heilmann-Clausen \& Christensen (2004), who reported that snags have the lowest importance for fungal diversity.

Stumps are a special case, as they often were not considered in previous studies. In many cases, especially in intensively used commercial forests, their availability as substratum for cryptogams is a consequence of tree cuttings, and the potential area exposed for colonization is relatively low compared to other types of dead wood. In spite of the above limitations, in our study stumps hosted a number of cryptogam species similar to snags and higher than standing dead trees. The potential importance of stumps was shown by the Chaor estimator of total species richness, whose value was about three times higher than the number of species recorded on this substrate. Despite the high number of stumps studied, this suggests that we may have missed a considerably high number of species, which might have biased our analyses. Therefore, the importance of stumps for cryptogam biodiversity should not be underestimated in this type of studies.

The total species richness of cryptogams on dead wood of Fraxinus excelsior and Quercus robur was only slightly higher than that found on Picea abies, though the latter species had only $16 \%$ abundance in the studied plots. Dead wood of Picea abies is widely accepted as being a very important substratum for saproxylic organisms, especially for wood-inhabiting fungi (Lindblad 1998), and our results confirmed such evidence. We also found other species to be quite important for rare cryptogams. Corylus avellana served as a good substrate for some epiphytic species (especially Metzgeria furcata, Frulania dilatata and Ulota crispa). However, saproxylic species rarely colonized hazelnut dead wood, probably due to its short longevity. We observed large differences in colonization rates among the decay stages of the different tree species. On average, only one fifth of the logs were colonized by rare cryptogam species, and most colonized logs (92.9\%) hosted one or two species only. On the other hand, every second Quercus robur log in the third decay stage hosted a rare cryptogam species, while Alnus glutinosa logs in the late decay stages were colonized in less than $2 \%$ of cases. Logs of Fraxinus excelsior were characterized by high colonization rates only in the earlier decay stage, hosting many rare cryptogam species, frequently epiphytes. Later, when epiphytes disappear, its value decreases. Colonization rates on dead wood of Picea abies
Tab. 4 - Cryptogam species colonization efficiency on CWD according to decay classes of different tree species.

\begin{tabular}{|c|c|c|c|c|c|c|}
\hline $\begin{array}{l}\text { Tree } \\
\text { species }\end{array}$ & $\begin{array}{l}\text { Decay } \\
\text { stage }\end{array}$ & $\begin{array}{c}\text { Total } \\
\text { number } \\
\text { of logs }\end{array}$ & $\begin{array}{l}\text { Number of } \\
\text { colonized } \\
\text { logs }\end{array}$ & $\begin{array}{l}\text { Colonization } \\
\text { efficiency, \% }\end{array}$ & $\begin{array}{c}\text { Number of } \\
\text { colonized } \\
\text { species }\end{array}$ & p \\
\hline Acer & 1 & 24 & 3 & 12.5 & 4 & - \\
\hline \multirow[t]{4}{*}{ platanoides } & 2 & 18 & 1 & 5.6 & 2 & - \\
\hline & 3 & 9 & 1 & 11.1 & 1 & - \\
\hline & 4 & 2 & 1 & 50.0 & 1 & - \\
\hline & Total & 53 & 6 & 11.3 & 7 & 0.2865 \\
\hline Alnus & 1 & 13 & 0 & 0.0 & 0 & - \\
\hline \multirow[t]{4}{*}{ glutinosa } & 2 & 18 & 4 & 22.2 & 3 & - \\
\hline & 3 & 28 & 7 & 25.0 & 4 & - \\
\hline & 4 & 59 & 1 & 1.7 & 1 & - \\
\hline & Total & 118 & 12 & 10.2 & 5 & 0.0013 \\
\hline Alnus & 1 & 11 & 1 & 9.1 & 2 & - \\
\hline \multirow{4}{*}{ incana } & 2 & 20 & 2 & 10.0 & 2 & - \\
\hline & 3 & 14 & 0 & 0.0 & 0 & - \\
\hline & 4 & 4 & 0 & 0.0 & 0 & - \\
\hline & Total & 49 & 3 & 6.1 & 4 & 0.6884 \\
\hline Betula & 1 & 14 & 1 & 7.1 & 1 & - \\
\hline \multirow[t]{4}{*}{ pendula } & 2 & 18 & 0 & 0.0 & 0 & - \\
\hline & 3 & 32 & 3 & 9.4 & 3 & - \\
\hline & 4 & 7 & 0 & 0.0 & 0 & - \\
\hline & Total & 71 & 4 & 5.6 & 3 & 0.7014 \\
\hline Carpinus & 1 & 6 & 2 & 33.3 & 4 & - \\
\hline \multirow[t]{4}{*}{ betulus } & 2 & 22 & 9 & 40.9 & 5 & - \\
\hline & 3 & 16 & 0 & 0.0 & 0 & - \\
\hline & 4 & 6 & 1 & 16.7 & 1 & - \\
\hline & Total & 50 & 12 & 24.0 & 8 & 0.0132 \\
\hline Fraxinus & 1 & 205 & 57 & 27.8 & 15 & - \\
\hline \multirow[t]{4}{*}{ excelsior } & 2 & 87 & 14 & 16.1 & 13 & - \\
\hline & 3 & 24 & 6 & 25.0 & 5 & - \\
\hline & 4 & 6 & 0 & 0.0 & 0 & - \\
\hline & Total & 322 & 77 & 23.9 & 20 & 0.0885 \\
\hline \multirow[t]{5}{*}{ Picea abies } & 1 & 99 & 15 & 15.2 & 5 & - \\
\hline & 2 & 118 & 43 & 36.4 & 9 & - \\
\hline & 3 & 174 & 41 & 23.6 & 13 & - \\
\hline & 4 & 45 & 8 & 17.8 & 7 & - \\
\hline & Total & 436 & 107 & 24.5 & 17 & 0.0019 \\
\hline Populus & 1 & 29 & 4 & 13.8 & 3 & - \\
\hline \multirow[t]{4}{*}{ tremula } & 2 & 69 & 14 & 20.3 & 6 & - \\
\hline & 3 & 36 & 14 & 38.9 & 7 & - \\
\hline & 4 & 2 & 0 & 0.0 & 0 & - \\
\hline & Total & 136 & 32 & 23.5 & 11 & 0.0638 \\
\hline & 1 & 33 & 0 & 0.0 & 0 & - \\
\hline \multirow{4}{*}{ robur } & 2 & 168 & 48 & 28.6 & 8 & - \\
\hline & 3 & 60 & 29 & 48.3 & 6 & - \\
\hline & 4 & 2 & 0 & 0.0 & 0 & - \\
\hline & Total & 263 & 77 & 29.3 & 10 & 0.0001 \\
\hline Tilia & 1 & 29 & 3 & 10.3 & 2 & - \\
\hline \multirow{4}{*}{ cordata } & 2 & 27 & 1 & 3.7 & 1 & - \\
\hline & 3 & 10 & 1 & 10.0 & 1 & - \\
\hline & 4 & 1 & 0 & 0.0 & 0 & - \\
\hline & Total & 67 & 5 & 7.5 & 3 & 0.5967 \\
\hline \multirow[t]{5}{*}{ Total } & 1 & 463 & 86 & 18.6 & 25 & - \\
\hline & 2 & 565 & 132 & 23.4 & 32 & - \\
\hline & 3 & 403 & 102 & 25.3 & 29 & - \\
\hline & 4 & 134 & 11 & 8.2 & 11 & - \\
\hline & Total & 1565 & 331 & 21.2 & 48 & 0.0001 \\
\hline
\end{tabular}

increased in correlation with the decomposition of wood. These results suggest that species richness and abundance of rare cryptogams is not just related to the dead wood amount present in the forest ecosystem, but most of all to its quality, i.e., tree species and type of substratum.

The results of previous studies on the importance of the size of dead wood for cryptogam total species richness are often incoherent. Several authors reported that more cryptogam species develop on FWD than on CWD (Ehnstrom \& Axelsson 2002, Dahlberg 2003, Heilmann-Clausen \& Christensen 2004, Norden et al. 2004), while others argued that CWD is much more important for total species richness than FWD (Andersson \& Hytteborn 1991, Kruys et al. 1999, Humphrey et al. 2002). In this study, the effect of the size of the dead wood unit on the total abundance of cryptogam species was depending on dead wood type. The total abundance of rare cryptogams is higher on FWD snags than 
on CWD snags, but conversely it is higher on CWD logs in comparison to downed FWD. At the same time, total species richness is higher on all the studied types of CWD, and over $40 \%$ of the species registered on dead wood are exclusive to CWD, while only one (Trichocolea tomentella, also developing on the forest floor) is exclusive to FWD. We may hypothesize that this could be due to the greater potential surface area available for colonization, and the greater range of microhabitats provided by CWD as compared with FWD. It should also be considered that CWD takes much longer to decompose completely, thereby providing a more lasting habitat for colonizing organisms. Consequently, the larger the piece of dead wood, the more relevant is expected to be for biodiversity and its conservation (Samuelsson et al. 1994, Bader et al. 1995, Svensson et al. 2014). In our opinion, CWD may replace FWD as a substrate for the development of cryptogams in forest ecosystems, but not the opposite.

In certain cases, the decay stages of dead wood can become very important for wood-inhabiting indicator species. Intermediate and late decay stages provide additional environmental heterogeneity and more niches, which allow for higher numbers of species to settle (Kruys et al. 1999). In our study, wood of intermediate decay stages was the most important for saproxylic cryptogams (71.4\% of all records). Although $25.2 \%$ of all cryptogam records were found on freshly fallen logs, these were mostly epiphytic species usually growing on live trees (e.g., Neckera pennata, Lejeunia cavifolia, Metzgeria furcata, etc.); thus it is likely that such species colonized the substrate before its death. Similar results were reported by Lindblad (1998), Renvall (1995), Bader et al. (1995), Heilmann-Clausen \& Christensen (2005), and Iršenaite \& Kutorga (2006). When a log starts to decay the bark falls down, epiphytic species gradually disappear and are replaced by saproxylic species. Therefore, fresh dead wood is important for rare cryptogam biodiversity as well, as it allows epiphytes to last longer in the ecosystem, and replenishes stocks of dead wood in the forest.

Previous studies reported that in coniferous forests the highest total species richness of lichens was found on dead wood at intermediate decay stages, while the highest total species richness of bryophytes was at the final decay stages (Soderstrom 1988, Kruys et al. 1999, Humphrey et al. 2002). In our study the species richness of all studied taxonomic groups was lower in the latest decay stages in comparison to intermediate decay stages. The species richness of bryophytes and macrolichens decreased with advancing wood decomposition. Most likely this was due to epiphytic species already present on live tree trunks, which are then replaced by saproxylic species, that retreated when the wood structure broke down. Different trends were observed for fungi, whose species richness peaked at the intermediate stages of wood decay. However, it should be taken into account that fungi colonized wood much earlier, but were not recorded as long as they developed fruiting bodies, which were most abundant in the second and third decay stages.

\section{Conclusions}

This study is based on sample plots chosen on a vast area across several countries, and included stands with different forest management and protection regimes. Our results stress the importance of all types of dead wood as a substrate for the development of rare cryptogam species. The selected study sites well represent the eastern and central European temperate deciduous lowland forests outside of the beech distribution range. Therefore, it is reasonable that our results may be extended to other forests of the same region.

Since only fine dead wood may be found in commercial stands, while coarse wood fragments are always missing, the diversity of cryptogam species is decreasing in such forests. Indeed, we demonstrated that CWD may replace FWD in terms of suitable habitats for cryptogams, but not vice versa. We found downed dead wood (logs) to be the most relevant substrate type for conservation of cryptogam species, as it is colonized by most species, including many exclusive species which do not develop on other substrata. Moreover, forest managers should not undervalue the importance of stumps for the conservation of cryptogam biodiversity. They are potentially as relevant as other types of dead wood, and their removal entails negative effects similar to the removal of dead standing trees or snags. We confirmed that due to the slow colonization by rare species, even in non-fragmented species-rich forest, only a small proportion of deadwood units are colonized by them, especially because the colonization rate depends on dead wood tree species and decay stage. In fact, a larger number of cryptogam species were observed in stands with dead wood of Quercus robur, Picea abies, Carpinus betulus, Fraxinus excelsior and Populus tremula (every fourth log of these species hosted rare cryptogams), as compared with those where dead wood of Betula pendula, Alnus incana and Tilia cordata was present (less than one tenth of logs were colonized).

Previous studies on the importance of dead wood for biodiversity were usually limited to few species or one systematic group of organisms, or concentrated on certain types of dead wood (Müller \& Bütler 2010). Since it is not feasible to survey all groups of organisms associated with dead wood, we propose the use of indicator species as a possible solution, allowing a compromise between work load and result reliability.

\section{Acknowledgments}

Many thanks to J. Motiejunaite, I. Jukoniene and R. Iršenaite for their help in the identification of some cryptogam species, M. Bobrovsky and the staff of the Kaluzhskye Zaseki Reserve for assistance in the organization of expeditions to Kaluga forests, V. Ivkovich for the expeditions to the Berezina Biosphere Reserve, A. Zalewska and A. Sulej for expeditions to forests in Poland. Special thanks to the Lithuanian Education Exchange Support Fund for financial support yo a study visit to Poland. BJ scientific involvement has been financed from resources earmarked for science by the Polish Ministry of Science and Higher Education in the years 2010-2014 for the accomplishment of the co-financed international project FunDivEurope (contract no. 265171).

\section{References}

Andersson LI, Hytteborn H (1991). Bryophytes and decaying wood - a comparison between managed and natural forest. Holarctic Ecology 14: 121-130. - doi: 10.1111/j.1600-0587.1991.tboo64 2.x

Andersson L, Kriukelis R, Ciuplys R (2002). Kertiniu miško buveiniu inventorizacijos metodika [Woodland key habitat inventory. Methodology]. Ministry of Environment Republic of Lithuania, Regional Forestry Board of Östra Götaland, Sweden, Vilnius-Linkoping, Lithuania, pp. 72. [in Lithuanian]

Bader P, Jannson S, Jannson BG (1995). Woodinhabiting fungi and substrate decline in selectively logged boreal spruce forests. Biological Conservation 72: 355-362. - doi: 10.1016/00063207(94)00029-P

Berg A, Ehnstrom B, Gustavsson L, Hallingback T, Jonsell M, Weslien J (1994). Threatened plant, animal and fungus species in Swedish forests: distribution and habitat associations. Conservation Biology 8: 718-731. - doi: 10.1046/j. 1523-1739.1994.08030718.x

Bobiec A (2012). Bialowieza primeval forest as a remnant of culturally modified ancient forest. European Journal of Forest Research. - doi: 10.1007/s10342-012-0597-6

Bunce RGH, Barr CJ, Whittaker HA (1983). A stratification system for ecological sampling. In: "Ecological mapping from ground, air and space” (Fuller RM eds). ITE Symposium 10, Institute of Terrestrial Ecology, Cambridge, UK, pp. 39-46. [online] URL: http://nora.nerc.ac.uk/ 6275/1/Noo6275CP.pdf

Burrascano S, Lombardi F, Marchetti M (2008). Old-growth forest structure and deadwood: are they indicators of plant species composition? A case study from central Italy. Plant Biosystems 142: 313-323. - doi: 10.1080/112635 00802150613

Chlebicki A, Zarnowiec J, Cieslinski S, Klama H, Bujakiewicz A, Zaluski T (1996). Epixylites lichenicolous fungi and their links with different kinds of wood. Phytocoenosis 8 (NS) Archivum Geobotanicum 6: 75-111.

Christensen M, Hahn K, Mountford EP, Odor P, Standovar T, Rozenbergar D, Diaci J, Wijdeven S, Meyer P, Winter S, Vrska T (2005). Dead wood in European beech (Fagus sylvatica) fo- 
rest reserves. Forest Ecology and Management 210: 267-282. - doi: 10.1016/j.foreco.2005.02.032 Colwell RK (2013). EstimateS: statistical estimation of species richness and shared species from samples (version 9). Web site. [online] URL: http://purl.oclc.org/estimates

Colwell RK, Coddington JA (1994). Estimating terrestrial biodiversity through extrapolation. Philosophical Transactions of the Royal Society B 345: 101-118. - doi: 10.1098/rstb.1994.0091 Dahlberg A (2003). Vedlevande arters krav pa kvaliteer av dod ved [Substrate requirements of saproxylic species in Sweden]. Swedish Threatened Species Unit, Uppsala, Sweden. [in Swedish with English summary]

Djupstrom LB, Weslien J, Schroeder LM (2008). Dead wood and saproxylic beetles in set-aside and non set-aside forests in a boreal region. Forest Ecology and Management 255 (8-9): 3340-3350. - doi: 10.1016/j.foreco.2008.02.015

Ehnstrom B, Axelsson R (2002). Insektsgnag i bark och ved [Galleries and exit holes of insects in bark and wood] Artdatabanken SLU, Uppsala, Sweden. [in Swedish with English summary]

Esseen PA, Ehnstrom B, Ericson L, Sjoberg K (1997). Boreal forests. Ecological Bulletin 43: 1647. [online] URL: http://www.jstor.org/stable/ 20113207

Falinski JB, Mulenko W (1995). Cryptogamous plants in the forest communities of Bialowieža national park: general problems and taxonomic groups analysis. Phytocoenosis 7, Archivum geobotanicum 4, Warszawa-Bialowieza, Poland, pp. 176.

Fenton NJ, Bergeron $\mathrm{Y}$ (2008). Does time or habitat make old-growth forests species rich? Bryophyte richness in boreal Picea mariana forests. Biological Conservation 141: 1389-1399. - doi: 10.1016/j.biocon.2008.03.019

Gricius A, Matelis A (1996). Afiloforiečiai 2 [Aphyllophorales]. Mokslas ir enciklopedijos, Vilnius, Lithuania, pp. 232.

Gustafsson L, De Jong J, Norén M (1999). Evaluation of Swedish woodland key habitats using red-listed bryophytes and lichens. Biodiversity and Conservation 8: 1101-1114. - doi: 10.1023/A:1 008934526658

Hannah L, Carr JL, Lankerani A (1995). Human disturbance and natural habitat: a biome level analysis of a global data set. Biodiversity and Conservation 4: 125-155. - doi: 10.1007/BF00137 781

Hanski I, Kouki J, Halkka A (1993). Three explanations of the positive relationship between distribution and abundance of species. In: "Species diversity in ecological communities" (Ricklefs RE, Schluter D eds). University of Chicago Press, Chicago, IL, USA, pp. 108-116.

Heilmann-Clausen J, Christensen M (2004). Does size matter? On the importance of various dead wood fractions for fungal diversity in Danish beech forests. Forest Ecology and Management 201: 105-117. - doi: 10.1016/j.foreco.2004.07 .010

Heilmann-Clausen J, Christensen M (2005). Wood-inhabiting macrofungi in Danish beechforests - conflicting diversity patters and their implications in a conservation perspective. Biological Conservation 122: 633-642. - doi: 10.1016/ j.biocon.2004.10.001
Humphrey JW, Davey S, Peace AJ, Ferris R, Harding $K$ (2002). Lichens and bryophyte communities of planted and semi-natural forests in Britain: the influence of site type, stand structure and deadwood. Biological Conservation 107: 165-180. - doi: 10.1016/So0o6-3207(02)0005 7-5

Huston MA (1996). Models and management implications of coarse wood debris impacts on biodiversity. In: Proceedings of the Workshop "Coarse Woody Debris in Southern Forests: Effects on Biodiversity" (McMinnn JW, Crossley DA eds). Athens (GA, USA) 18-20 Oct 1993. USDA Forest Service, Athens, GA, USA, pp. 139143. [online] URL: https://books.google.it/book s?id=9B3980OPKJIC

Iršenaite R, Kutorga E (2006). Diversity of fungi on decaying common oak coarse woody debris. Ekologija 4:22-30. [online] URL: http://elibrary. It/resursai/LMA/Ekologija/Eko64/Eko64_07.pdf Jacobs JM, Spence JR, Langor DW (2007). Influence of boreal forest succession and dead wood qualities on saproxylic beetles. Agricultural and Forest Entomology 9 (1): 3-16. - doi: 10.1111/j.1461-9563.2006.00310.x

Jaeger TF (2008). Categorical data analysis: away from ANOVAs (transformation or not) and towards logit mixed models. Journal of Memory and Language 59: 434-446. - doi: 10.1016/j.jml.2007.11.007

Jukoniene I (2003). Lietuvos kiminai ir žaliosios samanos [Sphagnum and green mosses of Lithuania]. Botanikos institutas, Vilnius, Lithuania, pp. 402.

Juutilainen K, Halme P, Kotiranta H, Monkkonen $M$ (2011). Size matters in studies of dead wood and wood-inhabiting fungi. Fungal Ecology 4 (5): 342-349. - doi: 10.1016/j.funeco.2011.05.004 Kruys N, Fries C, Jonsson BG, Lamas T, Stahl G (1999). Wood-inhabiting cryptogams on dead Norway spruce (Picea abies) trees in managed Swedish boreal forests. Canadian Journal of Forest Research 29: 178-186. - doi: 10.1139/x98-191 Kuusinen M (1995). Epiphytic lichen diversity on Salix caprea and Populus tremula in old-growth forests of Finland. Mitt. Eidgenoss. Forsch. Anst. Wald Schnee Landsch 70: 125-132. [online] URL: http://www.wsl.ch/dienstleistungen/publi kationen/pdf/829.pdf\#page=124

Kuusinen M (1996a). Cyanobacterial macrolichens on Populus tremula as indicators of forest continuity in Finland. Biological Conservation 75: 43-49. - doi: 10.1016/0006-3207(95)0003 9-9

Kuusinen M (1996b). Epiphytic lichen flora and diversity in old-growth boreal forests of Finland. Publications in Botany from the University of Helsinki 23: 1-29.

Kuusinen M, Siitonen J (1998). Epiphytic lichen diversity in old-growth and managed Picea abies stands in southern Finland. Journal of Vegetation Science 9: 283-292. - doi: $10.2307 / 3237$ 127

Lindblad I (1998). Wood-inhabiting fungi on fallen logs of Norway spruce: relations to forest management and substrate quality. Nordic Journal of Botany 18: 243-255. - doi: 10.1111/j. 1756-1051.1998.tbo1877.x

Lindholm M (2001). Epixyla lavar och mosssormagfald i relation till habitets variation [Epixylic lichens and mosses - diversity in relation to habitats variation]. Masters Thesis. Goteborg University, Sweden. [in Swedish]

Lindenmayer DB, Margules CR, Botkin DB (2000). Indicators of biodiversity for ecologically sustainable forest management. Conservation Biology 14 (4): 941-950. - doi: 10.1046/j.15231739.2000.98533.x

Lohmus P, Lohmus A (2001). Snags and their lichen flora in old Estonian peatland forests. Annales Botanici Fennici 38: 265-280.

Lundborg A (1998). A sustainable forest fuel system in Sweden. Biomass Energy 15: 399-406. doi: 10.1016/Sog61-9534(98)00046-4

Malinen J, Pesonen M, Maatta T, Kajanus M (2001). Potential harvest for wood fuels (energy wood) from logging residues and first thinnings in Southern Finland. Biomass Energy 20: 189-196. - doi: 10.1016/So961-9534(00)00075-1

McAlister S (1997). Cryptogam communities on fallen logs in the Duke Forest, North Carolina. Journal of Vegetation Science 8: 115-124. - doi: $10.2307 / 3237249$

Motiejunaite J (2002). Lapiškosios ir krumiško sios kerpes [Ascomycetes lichenisati. Species foliosae et fruticosae]. Valstiečiu laikraštis, Vilnius, Lithuania, pp. 311.

Motiejunaite J, Czyžewska K, Cieslinski S (2004). Lichens - indicators of old-growth forests in biocentres of Lithuania and north-east Poland. Botanica Lithuanica 10 (1): 59-74. [online] URL: http://web.b.ebscohost.com/abstract?h=mfN1F Müller J, Bütler R (2010). A review of habitat thresholds for dead wood: a baseline for management recommendations in European forests. European Journal of Forest Research 129: 981-992. - doi: 10.1007/s10342-010-0400-5

Naujalis J, Kalinauskaite N, Grinevičiene M (1995). Vadovas Lietuvos kerpems pažinti [Manual for identification of liverworts of Lithuania]. Zodynas, Vilnius, Lithuania, pp. 244. Niemelä T, Renvall P, Pentilla R (1995). Interaction of fungi at late stages of wood decomposition. Annales Botanici Fennici 32: 141-150.

Nilsson SG, Hedin J, Niklasson M (2001). Biodiversity and its assessment in boreal and nemoral forests. Scandinavian Journal of Forest Research (Supplement 3): 10-26. - doi: 10.10 80/028275801300090546

Nitare J, Norén M (1992). Nyckelbiotoper kartläggs i nytt projekt vid Skogsstyrelsen [Key habitats identified in the new project at the National Board of Forestry]. Svensk Bot Tidskr 86: 219-226 [in Swedish with English abstract] Norden B, Ryberg M, Gotmark F, Olausson B (2004). Relative importance of coarse and fine woody debris for the diversity of wood-inhabiting fungi in temperate broadleaved forests. Biological Conservation 117: 1-10. - doi: 10.1016/S 0006-3207(03)00235-0

Odor P, Van Hees AFM (2004). Preferences of dead wood inhabiting bryophyte for decay stage, log size and habitat types in Hungarian beech forests. Journal of Bryology 26: 79-95. doi: 10.1179/037366804225021038

Ohlsson M, Soderstrom L, Hornberg G, Zackrisson O, Hermansson J (1997). Habitat qualities versus long-term continuity as determinants of biodiversity in boreal old-growth swamp forests. Biological Conservation 81: 221-231. - doi: 10.1016/Sooo6-3207(97)00001-3

Qian H, Klinka K, Song X (1999). Cryptogams on 
decaying wood in old-growth forests on southern coastal British Columbia. Journal of Vegetation Science 10: 883-894. - doi: 10.2307/3237313 Quinn GP, Keough MJ (2002). Experimental design and data analysis for biologists. Cambridge University Press, Cambridge, UK, pp. 527. [online] URL: http://books.google.com/ books?id=VtU3-y7LaLYC

Peterken GF (1996). Natural woodland-ecology and conservation in northern temperate regions. Cambridge University Press, Cambridge, UK, pp. 522. [online] URL: http://books.google. com/books?id=p3y43NnvXPYC

Ranius T, Fahrig L (2006). Targets for maintenance of dead wood for biodiversity conservation based on extinction thresholds. Scandinavian Journal of Forest Research 21: 201-208. doi: $10.1080 / 02827580600688269$

Renvall P (1995) Community structure and dynamics of wood-rotting Basidiomycetes on decomposing conifer trunks in northern Finland. Karsten 35: 1-51.

Rivas-Martinez S, Penas A, Diaz TE (2004). Bioclimatic map of Europe: bioclimates. Cartographic Service, University of Leon, Spain. [online] URL: http://www.globalbioclimatics.org/form/maps. htm

Rose F (1992). Temperate forest management: its effects on bryphyte and lichen floras and habitats. In: "Bryophytes and Lichens in a Changing Environment" (Bates JW, Farmer AM eds). Clarendon Press, Oxford, UK, pp. 211-233.

Samuelsson J, Gustafsson L, Ingelog T (1994). Dying and dead trees - a review of their importance for biodiversity. ArtDatabanken, Uppsala, Sweden.

Schielzeth H, Nakagava S (2013). Nested by design: model fitting and interpretation in a mixed model era. Methods in Ecology and Evolution 4: 14-24. - doi: 10.1111/j.2041-210x.2012.002 51.x

Siitonen J (2001). Forest management, coarse woody debris and saproxylic organisms: Fennoscandian boreal forests as an example. Ecological Bulletin 49: 11-41. [online] URL: http:// www.jstor.org/stable/20113262

Soderstrom L (1988). The occurrence of epixylic bryophyte and lichen species in an old natural and a managed forest stand in northeast Sweden. Biological Conservation 45: 169-178. - doi: 10.1016/0006-3207(88)90137-1

Stevens V (1997). The ecological role of coarse woody debris: an overview of the ecological importance of CWD in BC forests. Working Paper 30/1997, Research Branch, BC Ministry of Forests, Victoria, British Columbia, Canada, pp.
26.

Svensson M, Dahlberg A, Ranius T, Thor C (2014). Dead branches on living trees constitute a large part of the dead wood in managed boreal forests, but are not important for wooddependent lichens. Journal of Vegetation Science 25: 819-828. - doi: 10.1111/jvs.12131

Ulicka H, Angelstam P (2000). Assessing conservation values of forest stands based on specialised lichens and birds. Biological Conservation 95: 343-351. - doi: 10.1016/Sooo6-3207(00) 00022-7

Waddell KL (2002). Sampling coarse woody debris for multiple attributes in extensive resource inventories. Ecological Indicators 1: 139-153. - doi: 10.1016/S1470-160X(01)00012-7

Walmsley JD, Godbold DL (2010). Stump harvesting for bioenergy - a review of the environmental impacts. Forestry 83: 17-38. - doi: 10.1093/forestry/cppo28

\section{Supplementary Material}

Appendix 1 - Old-growth forest indicator species of cryptogams registered during the study.

Link: Preiksa_1483@supplo01.pdf 